\title{
HUBUNGAN ANTARA KARAKTERISTIK DAN PENGETAHUAN DENGAN PEMBERIAN ASI SECARA EKSKLUSIF PADA IBU YANG MEMPUNYAI BAYI USIA 0-6 BULAN DI PUSKESMAS KAMPUNG DALAM TAHUN 2018
}

\author{
Alexander ${ }^{1}$, Melyani ${ }^{2}$, Lindawati ${ }^{3}$ \\ Akademi Kebidanan Panca Bhakti Pontianak \\ Email korespondensi: akbidpbpontianak@gmail.com
}

\begin{abstract}
Abstrak
ASI secara Eksklusif adalah pemberian ASI saja selama 6 bulan tanpa tambahan cairan apapun, seperti susu formula, jeruk, madu, air teh, air putih dan tanpa pemberian makanan tambahan padat, seperti pisang, pepaya,bubur susu, biskuit, bubur nasi dan tim. Pemberian ASI secara Eksklusif di Puskesmas Kampung Dalam masih relatif rendah (56,37\%), masih ada ibu yang tidak memberikan ASI secara Eksklusif dengan berbagai alasan. Tujuan dari penelitian ini adalah untuk mengetahui hubungan antara karakteristik, dan pengetahuan dengan pemberian ASI secara Eksklusif pada ibu yang mempunyai bayi usia 0-6 bulan di Puskesmas Kampung Dalam tahun 2018. Metode penelitian yang digunakan adalah analitik kolerasi, dengan pendekatan cross sectional teknik sampling menggunakan purposive sampling. Sampel penelitian ini adalah ibu yang mempunyai bayi usia 0-6 bulan di Puskesmas Kampung Dalam tahun 2018 yaitu 36 responden. Analisa data menggunakan uji chi square untuk mencari hubungan antar variabel. Hasil uji chi square menunjukan tidak ada hubungan antara karakteristik (umur, paritas, status ekonomi). Tetapi ada hubungan antara karakteristik (pendidikan,pekerjaan, social budaya), dan pengetahuan dengan pemberian ASI secara Eksklusif di Puskesmas Kampung Dalam tahun 2018. Hasil pengukuran variabel yang berhubungan, yaitu: pendidikan $(\mathrm{p}=0,013)$, pekerjaan $(0,048)$, sosial budaya $(0,008)$, dan pengetahuan $(\mathrm{p}=0,030)$. Oleh karena itu, perlu adanya upaya peningkatan pengetahuan di masyarakat oleh tenaga kesehatan terutama tentang pemberian ASI secara Eksklusif agar pemberian ASI secara Eksklusif semakin bertambah, dan target nasional pemberian ASI secara eKsklusif yaitu $80 \%$ dapat tercapai.
\end{abstract}

Kata Kunci : Karakteristik, Pengetahuan, Pemberian ASI Secara Eksklusif

\section{Pendahuluan}

Pemberian ASI secara Eksklusif adalah pemberian hanya ASI saja selama 6 bulan tanpa tambahan cairan apapun, seperti susu formula, jeruk, madu, air teh, air putih dan tanpa pemberian makanan tambahan padat, seperti pisang, pepaya, bubur susu, biskuit, bubur nasi dan tim. (Maryunani, 2015).

\section{Menurut World Health Organization} (WHO) (2016) dalam penelitian Safitri (2016) menjelaskan bahwa pemberian ASI secara Eksklusif memiliki banyak manfaat bagi ibu dan bayi, beberapa manfaat ASI bagi bayi yaitu sebagai perlindungan terhadap infeksi

\footnotetext{
${ }^{1}$ Dosen Akademi Kebidanan Panca Bhakti Pontianak

2 Dosen Akademi Kebidanan Panca Bhakti Pontianak

${ }^{3}$ Mahasiswa Akademi Kebidanan Panca Bhakti Pontianak
}

gastrointestinal, menurunkan risiko kematian bayi akibat diare dan infeksi, sebagai sumber energi dan nutrisi bagi anak usia 6-24 bulan, serta mengurangi angka kematian anak yang kekurangan gizi. Sedangkan manfaat pemberian ASI bagi ibu yaitu mengurangi risiko kanker ovarium dan payudara, kelancaran produksi ASI, metode keluarga berencana $(\mathrm{KB})$ alamiah, dan membantu mengurangi berat badan (BB) lebih cepat setelah kehamilan (Safitri, 2016).

Cakupan angka keberhasilan pemberian ASI secara Eksklusif di seluruh dunia hanya 
40\% (WHO, 2018). Pemberian ASI secara Eksklusif di negara ASEAN masih cukup rendah, antara lain yaitu: India (46\%), Filipina (34\%), Vietnam (27\%), dan Myanmar (24\%) (Cristiana, 2016).

Berdasarkan kajian global The Lancet Breastfeeding Series (2016) dalam Pedoman ASI (2017), menyatakan bahwa pemberian ASI secara Eksklusif dapat menurunkan Angka Kematian Bayi (AKB) akibat infeksi sebesar $88 \%$. Kemudian, memberikan ASI secara Eksklusif juga berkontribusi terhadap penurunan risiko stunting, obesitas, dan penyakit kronis di masa yang akan datang serta perilaku tidak memberikan ASI secara Eksklusif juga berhubungan dengan kehilangan nilai ekonomi sekitar 302 milyar dolar setiap tahunnya atau sebesar 0-49\% dari pendapatan nasional bruto (Kemenkes RI, 2017).

Berkaitan dengan hal tersebut, untuk mengurangi angka kesakitan dan kematian bayi maka World Health Organization (WHO) dan United Nations Childrens Fund (UNICEF) (2016) merekomendasikan agar ibu menyusui bayinya saat 1 jam pertama setelah melahirkan hingga bayi berusia 6 bulan pertama di masa kehidupannya (Safitri, 2016). Bayi yang diberi ASI secara Eksklusif akan terlihat lebih sehat, cerdas, serta memiliki IQ yang tinggi, EQ dan SQ yang lebih baik dari pada bayi yang di beri susu formula (Nirwana, 2014).

Berdasarkan data yang dikumpulkan International Baby Food Action Network (IBFAN) (2014), menyatakan bahwa Indonesia menduduki peringkat ke 3 terbawah dari 51 negara di dunia dalam penilaian status kebijakan program pemberian makan bayi dan anak, serta jika dilihat dari Angka Kematian Bayi (AKB) pada tahun 2015 menunjukkan angka kematian sebesar 22,23\% (Kemenkes RI, 2016).

Hal tersebut disebabkan karena bayi yang tidak mendapatkan ASI mengalami kurang gizi, dan tidak melakukan Inisiasi Menyusui Dini (IMD). Padahal, pemberian ASI awal untuk 1 jam pertama kehidupan bayi banyak mengandung kolostrum yang bermanfaat sebagai antibodi, pencahar, serta sebagai sumber protein bagi bayi (Dahlan, 2014).

Cakupan pemberian ASI secara Eksklusif di Indonesia mengalami fluktuatif setiap tahunnya, pada tahun 2015 (41,9\%), dan pada tahun 2016(29,5\%). Tiga provinsi dengan capaian pemberian ASI secara Eksklusif tertinggi yaitu Nusa Tenggara Timur $(79,9 \%)$, Papua (76,2\%) dan Nusa Tenggara Barat $(72,8 \%)$ dan tiga provinsi terendah adalah Kalimantan Tengah (40\%), Riau (39,7\%) dan Gorontalo (32,3\%) (Kemenkes 2016).

Cakupan ASI secara Eksklusif di provinsi Kalimantan Barat juga masih rendah, bahkan mengalami penurunan dari tahun sebelumnya. Jumlah pemberian ASI secara Eksklusif pada bayi sampai usia 6 bulan sebesar $22,9 \%$ sehingga belum memenuhi target pemberian ASI Eksklusif secara nasional yaitu sebesar 80\% (Kemenkes RI, 2016).

Walaupun begitu banyak manfaat ASI baik bagi bayi maupun ibu, minat ibu dalam memberikan ASI masih rendah, banyak faktor yang mempengaruhi angka keberhasilan 
pemberian ASI secara Eksklusif antara lain: faktor masa lalu (primipara atau multipara), faktor internal (usia, pendidikan, karakter, dan sosial budaya, dan gaya hidup), faktor eksternal (lingkungan, petugas kesehatan) serta pendidikan kesehatan yang akan mempengaruhi pengetahuan ibu mengenai masa nifas dan menyusui (Maritalia, 2017). Dan faktor lainnya adalah status pekerjaan yang membuat seorang ibu berhenti menyusui (Pujiastuti, 2016).

Rendahnya pemberian ASI secara Eksklusif di pengaruhi oleh faktor usia, yaitu ibu yang berusia 18 tahun akan berbeda dalam melewati masa nifas dan menyusui dibandingkan dengan ibu yang berusia 40 tahun (Maritalia, 2017). Dalam penelitian Nurbayanti (2016), menjelaskan bahwa lbu yang berumur kurang dari 20 tahun masih belum matang dan belum siap dalarn hal jasmani dan sosial dalarn menghadapi kehamilan, persalinan serta dalam mengasuh bayi yang dilahirkan, ibu yang berumur 20-35 tahun baik dalam masa reproduksi, tenang secara emosional terutama dalarn menghadapi kehamilan, persalinan, dan nifas sedangkan pada ibu dengan usia 35 tahun ke atas dimana produksi hormon laktasi sudah menurun.

Persiapan masa nifas bagi Ibu yang primipara tentu akan berbeda dengan ibu multipara, ibu primipara belum pernah berpengalaman, dan sangat minim informasi dalam hal merawat bayi dan menyusui (Maritalia, 2017). Semakin tinggi tingkat pendidikan seseorang, maka tuntutannya terhadap kualitas kesehatan akan semakin tinggi. Tidak dapat dipungkiri bahwa makin tinggi pendidikan seseorang semakin mudah pula mereka menerima informasi, dan pada akhirnya makin banyak pula pengetahuan yang dimilikinya (Mubarak, dkk 2012). Ibu yang berpendidikan tinggi akan berbeda dalam mempersiapkan dan melakukan perawatan dirinya saat masa nifas dan menyusui dibandingkan dengan yang berlatar belakang pendidikan rendah (Maritalia, 2017).

Tidak sedikit ibu yang menganggap remeh pemberian ASI secara Eksklusif, terutama pada ibu yang bekerja. Menurut Suharyono, dkk (2006) dalam penelitian Nurbayanti (2016) menyatakan bahwa ibu yang bekerja dapat mempengaruhi kualitas dalam pemberian ASI sedangkan Ibu yang tidak bekerja lebih banyak memiliki waktu luang untuk memberikan ASI secara Eksklusif kepada bayinya dan bagi ibu bekerja alasan yang dipakai adalah supaya membiasakan bayi menyusu dari botol bila nanti ditinggal bekerja.

Keluarga dengan status ekonomi tinggi cenderung sering membeli susu formula, sedangkan ibu dengan status ekonomi rendah akan memberikan ASI secara Eksklusif sehingga menghemat pengeluaran keluarga (Karima, 2015). Hal ini tidak hanya memberikan manfaat bagi keluarga, tetapi juga bagi rumah sakit maupun pemerintah atau negara untuk berhemat dalam pembelian susu buatan (Maritalia, 2017). Banyak adat istiadat atau tradisi keluarga yang harus tetap dipertahankan dan dilakukan pada ibu yang menyusui, seperti sejumlah kebudayaan yang menganggap bahwa tindakan memberikan air, 
cairan manis kepada bayi baru lahir sebagai cara menyambut kehadirannya di dunia, padahal pemberian ASI secara Eksklusif harus sampai bayi berusia 6 bulan (Maryunani, 2015).

Penelitian Mufydah (2016) menjelaskan bahwa meskipun pemberian ASI secara Eksklusif telah banyak disosialisasikan, namun tidak sedikit Ibu yang memiliki pengetahuan kurang sehingga cenderung memiliki perilaku yang kurang baik dalam pemberian ASI secara Eksklusif, sehingga timbul persepsi bahwa pemberian susu formula dapat menjadi alternatif sebagai pengganti ataupun pendamping ASI. Berdasarkan studi pendahuluan yang dilakukan peneliti di Puskesmas Kampung Dalam, data yang di dapat mengenai pemberian ASI secara Eksklusif dan tidak Eksklusif tahun 2017 jumlah bayi yang mendapatkan ASI tidak Eksklusif sebanyak 610 jiwa (56,37\%), dan jumlah bayi yang mendapatkan ASI secara Eksklusif sebanyak 472 jiwa (43,63\%). Bulan Januari sampai dengan bulan Februari tahun 2018, jumlah bayi yang ASI tidak Eksklusif sebanyak 80 jiwa $(55,94 \%)$, dan jumlah bayi yang diberi ASI secara Eksklusif sebanyak 63 jiwa $(44,06 \%)$.

Studi pendahuluan yang dilakukan, diketahui bahwa pencapaian ASI secara Eksklusif di Puskesmas Kampung Dalam masih rendah, dan melalui hasil wawancara kepada 5 responden yang mempunyai bayi berumur 0-6 bulan, didapatkan hasil bahwa 2 responden tidak mengetahui sama sekali mengenai pemberian ASI secara Eksklusif dan beranggapan bahwa susu formula dapat menjadi pengganti ASI selama ibu bekerja, dan pemberian ASI baikjika di tambahkan dengan air putih dengan harapan agar bayi kenyang, hal ini juga dikarenakan oleh pendidikan ibu yang relatif rendah yaitu 1 responden yang tamat Sekolah Dasar (SD) dan 1 responden yang tamat Sekolah Menegah Pertama (SMP). Oleh karena itu, peneliti tertarik untuk melakukan penelitian mengenai "Hubungan Antara Karakteristik dan Pengetahuan Dengan Pemberian ASI Secara Eksklusif Pada Ibu Yang Mempunyai Bayi Usia 0-6 Bulan Di Puskesmas Kampung Dalam Tahun 2018'. Sehingga, nantinya dapat dipergunakan sebagai bahan pertimbangan dalam meningkatkan penyuluhan kepada ibu- ibu mengenai pentingnya pemberian ASI secara Eksklusif pada bayi.

\section{Metode}

Penelitian ini menggunakan metode analitik korelatif dengan pendekatan rancangan cross sectional. Sampel dalam penelitian ini adalah seluruh ibu yang memiliki bayi yang berusia 0 6 bulan periode Januari sampai dengan bulan Februari tahun 2018 yaitu sebanyak 36 orang. Pengumpulan data menggunakan kuesioner kemudian diolah dan dianalisis menggunakan analisis univariat serta analisis bivariat menggunakan uji chi square 


\section{Hasil dan Pembahasan}

Tabel 1. Distribusi Frekuensi Hubungan Antara Karakteristik Dengan Pemberian ASI Secara Eksklusif Di Puskesmas Kampung Dalam Tahun 2018

\begin{tabular}{|c|c|c|c|c|c|}
\hline \multirow{3}{*}{ Karakteristik } & \multicolumn{4}{|c|}{ Pemberian Asi Eksklusif } & \multirow{3}{*}{ P Value } \\
\hline & \multicolumn{2}{|c|}{$\begin{array}{c}\text { Tidak } \\
\text { Memberikan }\end{array}$} & \multicolumn{2}{|c|}{ Memberikan } & \\
\hline & $\mathrm{N}$ & $\%$ & $\mathrm{~N}$ & $\%$ & \\
\hline \multicolumn{6}{|l|}{ Usia } \\
\hline$<20$ tahun & 5 & 41,7 & 7 & 58,3 & \multirow{3}{*}{0,090} \\
\hline 20-35 tahun & 10 & 76,9 & 3 & 23,1 & \\
\hline$>35$ tahun & 4 & 36,4 & 7 & 63,6 & \\
\hline \multicolumn{6}{|l|}{ Paritas } \\
\hline 1 & 6 & 54,5 & 5 & 45,5 & \multirow{3}{*}{1,000} \\
\hline $2-4$ & 13 & 52 & 12 & 48 & \\
\hline \multicolumn{5}{|l|}{ Pendidikan } & \\
\hline Rendah & 11 & 84,6 & 2 & 15,4 & \multirow{3}{*}{0,013} \\
\hline Menengah & 5 & 41,7 & 7 & 58,3 & \\
\hline Tinggi & 3 & 27,3 & 8 & 72,7 & \\
\hline \multicolumn{6}{|l|}{ Pekerjaan } \\
\hline Tidak Bekerja & 5 & 31,2 & 11 & 68,8 & \multirow{3}{*}{0,048} \\
\hline Bekerja & 14 & 70 & 6 & 30 & \\
\hline \multicolumn{5}{|l|}{ Status Ekonomi } & \\
\hline Sedang & 11 & 47,8 & 12 & 52,2 & \multirow{3}{*}{0,657} \\
\hline Tinggi & 8 & 61,5 & 5 & 38,5 & \\
\hline \multicolumn{5}{|l|}{ Sosial Budaya } & \\
\hline Tidak Mendukung & 16 & 72,7 & 6 & 27,3 & \multirow{2}{*}{0.008} \\
\hline Mendukung & 3 & 21,4 & 11 & 78,6 & \\
\hline
\end{tabular}

Hasil penelitian karakteristik umur responden yang menunjukkan bahwa hasil analisa nilai $\mathrm{p}$ value $(0,090)>\alpha$ yang berarti $\mathrm{Ha}$ ditolak dan Ho diterima sehingga tidak ada hubungan antara karakteristik usia dengan pemberian ASI secara Eksklusif. Karakteristik paritas responden di peroleh nilai $\mathrm{p}$ value $(1,000)>\alpha$ yang berarti Ha ditolak dan Ho diterima sehingga tidak ada hubungan antara karakteristik usia dengan pemberian ASI secara Eksklusif.

Karakteristik pendidikan responden di peroleh nilai $\mathrm{p}$ value $(0,013)<\alpha$ yang berarti $\mathrm{Ha}$ diterima dan Ho ditolak sehingga ada hubungan antara karakteristik pendidikan dengan pemberian ASI secara Eksklusif. Karakteristik pekerjaan responden di peroleh nilai $\mathrm{p}$ value $(0,048)<\alpha$ yang berarti Ha diterima dan Ho ditolak sehingga ada hubungan antara karakteristik pekerjaan dengan pemberian ASI secara Eksklusif. Karakteristik status ekonomi responden peroleh nilai $\mathrm{p}$ value $(0,650)>\alpha$ yang berarti Ha ditolak dan Ho diterima sehingga tidak ada hubungan antara karakteristik status ekonomi dengan pemberian ASI secara Eksklusif. 
Tabel 2 Distribusi Frekuensi Hubungan Antara Pengetahuan dengan Pemberian ASI Secara Eksklusif Di Puskesmas Kampung Dalam Tahun 2018

\section{Pemberian Asi Eksklusif}

\begin{tabular}{lccccc}
\cline { 2 - 5 } \multicolumn{1}{c}{ Karakteristik } & \multicolumn{2}{c}{ Tidak } & \multicolumn{2}{c}{ Memberikan } & P Value \\
& \multicolumn{2}{c}{ Memberikan } & & \\
\cline { 2 - 5 } & $\mathrm{N}$ & $\%$ & $\mathrm{~N}$ & $\%$ & \\
\hline Pengetahuan & 9 & 81,8 & 2 & 18,2 & \multirow{2}{*}{0,030} \\
Kurang $(<60)$ & 6 & 54,5 & 5 & 45,5 & \\
Cukup (60-75) & 4 & 28,6 & 10 & 71,4 & \\
Baik $(>75)$ & &
\end{tabular}

Hasil penelitian pengetahuan responden yang menunjukkan hasil analisa, di peroleh nilai p value $(0,030)<\alpha$ yang berarti Ha diterima dan Ho ditolak sehingga ada hubungan antara pengetahuan dengan pemberian ASI secara Eksklusif.

\section{Hubungan Usia Dengan Pemberian ASI Secara Eksklusif}

Hasil uji bivariat menunjukkan nilai $\mathrm{p}$ value $0,090>0,05$ yang berarti bahwa Ho diterima dan Ha ditolak yang menunjukkan bahwa tidak ada hubungan yang signifikan antara usia dengan pemberian ASI secara Eksklusif. Walaupun secara statistik menunjukkan tidak ada hubungan yang signifikan, namun data memperlihatkan bahwa ibu yang berumur $<20$ tahun lebih banyak tidak memberikan ASI secara Ekslusif $(41,7 \%)$ dibandingkan dengan ibu yang berumur $>35$ tahun yang tidak memberikan ASI secara Eksklusif (36,4\%).

Hal ini sesuai dengan teori Maritalia (2017), yang menjelaskan bahwa umur akan mempengaruhi kemampuan dan kesiapan diri ibu dalam melewati masa nifas dan menyusui. Ibu yang berusia 18 tahun akan berbeda dalam melewati masa nifas dan menyusui dibandingkan dengan ibu yang berusia 40 tahun. Hal ini sejalan dengan penelitian Untari (2017) yang berjudul "Hubungan Antara Karakteristik Ibu Dengan Pemberian ASI Eksklusif Di Wilayah Kerja Puskesmas Minggir Kabupaten Sleman" yang di dapatkan hasil bahwa tidak ada hubungan yang signifikan antara umur dengan pemberian ASI secara Eksklusif.

\section{Hubungan Paritas Dengan Pemberian ASI Secara Eksklusif}

Hasil uji bivariate menunjukkan nilai $\mathrm{p}$ value $1,000>0,05$ yang berarti bahwa Ho diterima dan Ha ditolak yang menunjukkan bahwa tidak ada hubungan yang signifikan antara paritas dengan pemberian ASI secara Eksklusif. Walaupun secara statistik menunjukkan tidak ada hubungan yang signifikan, namun data memperlihatkan bahwa ibu dengan paritas 2-4 lebih banyak memberikan ASI secara Eksklusif (48\%), jika dibandingkan dengan ibu yang paritas 1 $(45,5 \%)$. Hal ini sesuai dengan teori Maritalia (2017) yang menjelaskan bahwa persiapan masa nifas bagi Ibu yang primipara tentu akan berbeda dengan ibu multipara, ibu primipara belum pernah berpengalaman, dan sangat 
minim informasi dalam hal merawat bayi dan menyusui.

Hal tersebut juga sejalan Hidajati (2012) dalam penelitian Istianganah (2017), yang mengatakan bahwa seorang ibu dengan anak pertamanya mungkin akan mengalami masalah saat menyusui hanya kurangnya pengetahuan cara menyusui yang benar sehingga menyebabkan ibu ragu untuk memberikan ASI secara Eksklusif pada bayinya. Hal ini sejalan dengan penelitian Untari (2017) yang berjudul "Hubungan Antara Karakteristik Ibu Dengan Pemberian ASI Eksklusif Di Wilayah Kerja Puskesmas Minggir Kabupaten Sleman" yang di dapatkan hasil bahwa tidak ada hubungan yang signifikan antara paritas dengan pemberian ASI secara Eksklusif.

\section{Hubungan Pendidikan Dengan Pemberian ASI Secara Eksklusif}

Hasil uji bivariat menunjukkan nilai $\mathrm{p}$ value $0,013<0,05$ yang berarti bahwa Ho ditolak dan Ha diterima yang menunjukkan bahwa ada hubungan yang signifikan antara pendidikan dengan pemberian ASI secara Eksklusif. Hal ini sesuai dengan teori Supradi, dkk (2012), yang menjelaskan bahwa tidak dapat dipungkiri bahwa makin tinggi pendidikan seseorang makin mudah pula mereka menerima informasi, dan pada akhirnya makin banyak pula pengetahuan yang dimilikinya. Hal ini juga sesuai dengan teori Maritalia (2017), ibu yang berlatar belakang pendidikan medis/paramedic akan berbeda saat masa nifas dan menyusui dibandingkan ibu yang berlatar belakang pendidikan non medis/paramedic. Hal ini sejalan dengan penelitian Yolanda (2014), tentang ' 'Hubungan Pendidikan Dan Pengetahuan Ibu Tentang Air Susu Ibu (ASI) Dengan Pemberian ASI Ekslusif Di Kelurahan Arok Dipo Wilayah Kerja Puskesmas Guguk Panjang Kota Bukittinggi", yang di dapatkan hasil bahwa ada hubungan yang signifikan antara pendidikan dengan pemberian ASI secara Eksklusif.

\section{Hubungan Pekerjaan Dengan Pemberian ASI Secara Eksklusif}

Hasil uji bivariat menunjukkan nilai $\mathrm{p}$ value $0,048<0,05$ yang berarti bahwa Ho ditolak dan $\mathrm{Ha}$ diterima yang menunjukkan bahwa ada hubungan yang signifikan antara pekerjaan dengan pemberian ASI secara Eksklusif. Hal ini sejalan dengan dengan teori Maryunani (2015) yang menjelaskan bahwa rendahnya pemberian ASI secara eksklusif sering dikaitkan dengan alasan ibu yang kesibukannya bekerja, padahal tidak ada yang bisa menandingi kualitas ASI, bahkan susu formula sekalipun. Hal ini sesuai dengan teori Mubarak, dkk (2012) dalam penelitian Saputri (2015), ibu yang bekerja lebih sedikit memiliki waktu untuk saling bertukar pendapat dan berinteraksi dengan orang lain, keadaan ini menyebabkan ibu menghentikan pemberian ASI, sedangkan ibu yang tidak bekerja memiliki waktu yang banyak untuk menyusui anaknya.

Hal ini sejalan dengan penelitian Nurbayanti (2016) tentang 'Karakteristik Ibu Yang Berhubungan Dengan Pemberian ASI Eksklusif Di Puskesmas Temon II Kulon Progo Yogyakarta" yang di dapatkan hasil 
bahwa ada hubungan yang signifikan antara pekerjaan dengan pemberian ASI secara Eksklusif.

\section{Hubungan Status Ekonomi Dengan Pemberian ASI Secara Eksklusif} Hasil uji bivariat menunjukkan nilai $\mathrm{p}$ value $0,657<0,05$ yang berarti bahwa Ho diterima dan Ha ditolak yang menunjukkan bahwa tidak ada hubungan yang signifikan antara status ekonomi dengan pemberian ASI secara Eksklusif. Walaupun secara statistik menunjukkan bahwa tidak ada hubungan yang signifikan, namun data menunjukkan bahwa ibu dengan status ekonomi tinggi lebih sedikit memberikan ASI secara Eksklusif $(38,5 \%)$, dibandingkan dengan ibu yang berstatus ekonomi sedang $(52,2 \%)$ dalam pemberian ASI secara Eksklusif.

Hal ini sesuai dengan teori Pujiastuti (2016), yang menjelaskan bahwa dengan memberikan ASI secara Ekslusif maka kedekatan ibu dengan bayi tetap dipertahankan, serta menghemat pendapatan ibu karena tidak perlu membeli susu formula. Ibu yang berpendapatan rendah cenderung memberikan ASI secara Eksklusif karena tidak berkesempatan membeli susu formula jika dibandingkan dengan ibu yang berpendapatan tinggi lebih berpeluang dalam membeli susu formula. Hal ini sesuai dengan penelitian Hartina (2017) tentang 'Hubungan Antara Status Sosial Ekonomi Dengan Pemberian ASI Eksklusif Pada Bayi Usia 6-12 Bulan Di Wilayah Kerja Puskesmas Bailang Kota Manado" yang di dapatkan hasil bahwa tidak ada hubungan yang signifikan antara status ekonomi dengan pemberian secara Eksklusif.

\section{Hubungan Sosial Budaya Dengan \\ Pemberian ASI Secara Eksklusif}

Hasil uji bivariat menunjukkan nilai $\mathrm{p}$

value $0,657<0,05$ yang berarti bahwa Ho diterima dan Ha ditolak yang menunjukkan bahwa tidak ada hubungan yang signifikan antara status ekonomi dengan pemberian ASI secara Eksklusif. Hal ini sejalan dengan teori Maryunani (2015) yang menjelaskan bahwa dari generasi ke generasi diturunkan keyakinan bahwa bayi sebaiknya diberikan cairan. Air dipandang sebagai sumber kehidupan yaitu suatu kebutuhan batin maupun fisik bayi sekaligus serta sejumlah kebudayaan yang menganggap bahwa tindakan memberikan air kepada bayi baru lahir sebagai cara menyambut kehadirannya di dunia. Kebiasaan memberi air putih dan cairan lain seperti teh, air manis, dan jus kepada bayi yang menyusui dalam bulanbulan pertama kehidupan bayi umumnya banyak dilakukan di negara Nigeria, Zambia, Tanzania, Mali, Turki, India, dan Filipina. Mengganti ASI dengan cairan yang sedikit atau tidak bergizi akan berdampak buruk terhadap kondisi bayi, daya tahan tubuh, serta pertumbuhan dan perkembangan bayi. Karena, pemberian cairan dan makanan dapat menjadi sarana masuknya sumber pathogen. Hal ini sejalan dengan dengan penelitian Chandradewi, dkk (2011) tentang 'Hubungan Sosial Budaya Dengan Pemberian ASI Pada Bayi Di Wilayah Kerja Puskesmas Keruak Kabupaten Lombok Timur" yang di dapatkan hasil bahwa ada hubungan yang signifikan antara sosial budaya 
dengan pemberian ASI secara Eksklusif.

\section{Hubungan Pengetahuan Dengan Pemberian ASI Secara Eksklusif}

Hasil uji bivariat menunjukkan nilai $\mathrm{p}$ value $0,030<0,05$ yang berarti bahwa Ho ditolak dan Ha diterima yang menunjukkan bahwa ada hubungan yang signifikan antara pengetahuan dengan pemberian ASI secara Eksklusif.Hal ini sesuai dengan teori Supradi, dkk (2012) yang menjelaskan bahwa pengetahuan berhubungan erat dengan pendidikan, tidak dapat dipungkiri bahwa makin tinggi pendidikan seseorang semakin mudah pula mereka menerima informasi, dan pada akhirnya makin banyak pula pengetahuan yang dimilikinya.

Ibu dengan pengetahuan yang baik memperhatikan asupan nutrisi bayi, berpengetahuan banyak seperti manfaat ASI Eksklusif, dan cara pemberian ASI baik dibandingkan dengan ibu yang berpengetahuan rendah. Hal ini sesuai dengan penelitian Septyasrini (2016) tentang ' Hubungan Antara Tingkat Pengetahuan Dan Status Pekerjaan Dengan Pemberian ASI Eksklusif Di Wilayah Kerja Puskesmas Banyudono 1 Boyolali Universitas Muhammadiyah Surakarta" di dapatkan hasil bahwa ada hubungan yang signifikan antara pengetahuan dengan pemberian ASI secara Eksklusif. Oleh karena itu, pemberian ASI secara Eksklusif tidak lepas dari pengaruh karakteristik seseorang seperti: umur, paritas, pendidikan, pekerjaan, status ekonomi, dan status budaya serta pengetahuan ibu. Namun, dari keseluruhan karakteristik yang mempengaruhi tersebut, lebih difokuskan atau dititikkan kepada faktor pendidikan ibu dan sosial budaya ibu yang berpeluang besar dalam mempengaruhi pemberian ASI secara Eksklusif.

\section{Kesimpulan}

Terdapat hubungan antara karakteristik (pendidikan, pekerjaan, sosial budaya) dengan pemberian ASI secara Eksklusif. Dan tidak terdapat hubungan antara karakteristik (usia, paritas, status ekonomi) dengan pemberian ASI secara Eksklusif pada ibu yang mempunyai bayi usia 0-6 bulan di Puskesmas Kampung Dalam tahun 2018. Terdapat hubungan antara pengetahuan dengan pemberian ASI secara Eksklusif pada ibu yang mempunyai bayi usia0- 6 bulan di Puskesmas Kampung Dalam tahun 2018. perlu adanya upaya peningkatan pengetahuan di masyarakat oleh tenaga kesehatan terutama tentang pemberian ASI secara Eksklusif agar pemberian ASI secara Eksklusif semakin bertambah, dan target nasional pemberian ASI secara eKsklusif yaitu $80 \%$ dapat tercapai.

\section{Daftar Pustaka}

Alwi, dkk, 2005. Kamus Besar Bahasa Indonesia. Jakarta: Departemen Pendidikan Nasional Balai PustakaArikunto, 2010. Prosedur Penelitian. Jakarta: PT Rineka Cipta

Dahlan, 2014. Asuhan Kebidanan Masa Nifas. Jawa Timur: Pelaksa Media

Dinas Kesehatan Provinsi Kalimantan Barat, 2015. Profil Kesehatan Kalimantan Barat. Pontianak: Dinkes

Hasan Iqbal, 2013. Analisis Data Penelitian dengan Statistik. Jakarta : PT Bumi Aksara 
Hidayat A Aziz, 2014. Metode Penelitian Kebidanan dan Teknik Analisis Data. Jakarta: Salemba Medika

Ini Milda, 2016. Nutrisi Pintar Ibu Hamil dan Menyusui Untuk Golongan Darah O. Jakarta: Bhuana Ilmu Populer

Karima Khaulana, dkk, 2015. Gizi Ibu dan Bayi. Jakarta: PT Raja Grafindo Persada Kemenkes RI, 2016.

Profil Kesehatan Indonesia. 2017. Pedoman Penyelenggaraan Pekan ASI Sedunia. Diambil dari: (http://www.depkes.go.id/resources/dow nload/infoterkini/pedoman_Penyelengga raan_Pekan_ASI_Sed unia_PAS.pdf), diakses pada tanggal 28 Februari 2018, jam 15:34 WIB

Khairunissa, 2013. Hubungan Karakteristik, Pengetahuan Dan Sikap Ibu Dengan Pemberian Mp-ASI Pada Bayi Di Wilayah Kerja Puskesmas Siantan Tengah. Diambil dari: (https://media.neliti.com/media/publicat ions/194616-ID-hubungan-

karakteristik- pengetahuan-dan-s.pdf), diakses pada tanggal 02 Mei 2018, Jam 11:30 WIB

Maritalia Dewi, 2017. Asuhan Kebidanan Pada Ibu Nifas. Yogyakarta: Gosyen Publishing

Maryunani Anik, 2015. Asuhan Ibu Nifas dan Asuhan Ibu Menyusui. Jakarta: In Media

Mubarak, dkk, 2012. Promosi Kesehatan Untuk Kebidanan. Jakarta: Salemba Medika

Nirwana Ade Benih, 2014. ASI dan Susu Formula. Yogyakarta: Nuha Medika

Notoadmodjo Soekidjo, 2010. Promosi Kesehatan. Jakarta: PT Rineka Cipta

, 2012. Metode Penelitian Kesehatan. Jakarta: PT Rineka Cipta

Oxorn, 2010. Patologi dan Fisiologi Persalinan. Yogyakarta: C.V Andi Offset
Prihartono J, 2014. Metode Penelitian Kedokteran dan Kesehatan Masyarakat. Makasar: Binarupa Aksara

Profil Kesehatan Puskesmas Kampung Dalam. 2017

Profil Kesehatan Puskesmas Kampung Dalam. 2018

Pujiastuti Wahyu, 2016. Asuhan Holistik Masa Nifas dan Menyusui. Yogyakarta: Transmedika

Safitri Indah, 2016. Faktor-Faktor Yang Mempengaruhi Kelancaran Produksi ASI Pada Ibu Menyusui Di Desa Bendan, Kecamatan Banyudono, Kabupaten Boyolali. Diambil dari: (http://eprints.ums.ac.id/47378/22/1.\% 20halaman\%20judul.pdf),diakses pada tanggal 01 Maret jam 03:08 WIB

Sugiyono, 2015. Metode Penelitian Tindakan Komprehensif. Bandung: Alfabeta

Sujarweni, 2014. Metodelogi Penelitian Keperawatan. Yogyakarta: Gava Media

Sunarsih, 2011. Asuhan Kebidanan Pada Ibu Nifas. Jakarta: Salemba Medika

Suyanto, 2014. Metode Penelitian Epidemiologi Cross Sectional. Yogyakarta: Bossscript

Yaniawati Poppy, 2016. Metodelogi Penelitian Kuantitatif, Kualitatif, dan Campuran. Bandung: PT Refika Aditama

WHO, 2018. Baby Food And Children. Diambil dari:(http://www.who.int/en/newsroom/fact-sheets/detail/infant-andyoung- child-feeding), diakses pada tanggal 28 Februari, jam 15:48 WIB 